\title{
Litterfall Dynamics and Nutrient Cycling in an Experimental Plantation of Peach Palm (Bactris gasipaes Kunth)
}

Júlio César Ribeiro ${ }^{1}$ (D) 0000-0001-8021-2000

Marcos Gervasio Pereira ${ }^{1}$ (i) 0000-0002-1402-3612

João Luiz Gadioli² (1) 0000-0001-5562-7239

Júlio Cesar Raposo de Almeida² (1) 0000-0002-1526-7192

\begin{abstract}
This study aimed to evaluate litterfall and nutrient dynamics in an experimental plantation of peach palm (Bactris gasipaes Kunth) in Taubaté, São Paulo, Brazil. Litterfall was collected monthly between March 2010 and May 2011, and the plant material was separated into leaflets and rachises. During the 15-month study period, the plantation produced $9.2 \mathrm{Mg} \mathrm{ha}^{-1}$ of litter (4.8 $\mathrm{Mg} \mathrm{ha}^{-1}$ of leaflets and $4.4 \mathrm{Mg} \mathrm{ha}^{-1}$ of rachises). Seasonal variations were observed in litter production and nutrient concentration. Litter deposition was the highest at the end of the dry season and at the beginning of the rainy season, that is, in months with low rainfall and lower minimum temperatures. Macronutrient return to the soil was estimated at $141.5 \mathrm{~kg} \mathrm{~N} \mathrm{ha}^{-1}, 24.8 \mathrm{~kg} \mathrm{P} \mathrm{ha}^{-1}, 78.2 \mathrm{~kg} \mathrm{~K} \mathrm{ha}^{-1}, 55.1 \mathrm{~kg} \mathrm{Ca} \mathrm{ha}^{-1}$, and $37.8 \mathrm{~kg} \mathrm{Mg} \mathrm{ha}^{-1}$.
\end{abstract}

Keywords: palm plantation, plant nutrition, macronutrient content, seasonal effect.

\section{INTRODUCTION AND OBJECTIVES}

The peach palm (Bactris gasipaes Kunth, Arecaceae) is native to Central America and the Amazon region (Kalil Filho et al., 2010) and widely cultivated in Latin America, Hawaii, Indonesia, and Malaysia (Steinmacher et al., 2011). In Brazil, peach palm cultivation has high socio-economic importance in several regions (Sousa et al., 2011) and it has attracted growing interest because of the market potential of the heart of palm and fruits for human consumption and of the leaves and other parts of the plant as animal feed (Lorenzi, 2010). The fruits contain considerable amounts of protein, oil, fiber, $\beta$-carotene (pro-vitamin A), vitamins B and C, and iron (Carvalho et al., 2009; Yuyama et al., 2005).

The tree grows in tuffs of one to 13 stems that can reach $20 \mathrm{~m}$ in height and $15-25 \mathrm{~cm}$ in diameter (Clement, Rival et al., 2009; Lorenzi, 2010). Stems are supported by a fibrous root system, with $75 \%$ of the roots extending $40 \mathrm{~cm}$ from the central stem to a depth of $20 \mathrm{~cm}$. The rachis ranges from 1.5 to $2.5 \mathrm{~m}$ in length. Leaves may grow to $3 \mathrm{~m}$ and are composed of up to 240 leaflets originating at different angles (Lorenzi, 2010). Inflorescence development occurs between August and October and is followed by fruiting from December to March. Edaphoclimatic conditions may affect growth and development, inducing off-season fruiting (Yuyama et al., 2005).

Because peach palm grows in tuffs, it is an economically and environmentally attractive species for heart of palm extraction. Different from other palm species, such as juçara (Euterpe edulis) and açaí (Euterpe oleracea) (Fernandes et al., 2013; Kalil Filho et al., 2010), peach palm yields several harvests of heart of palm per year and has high production and adaptation capacity. In large-scale production systems, trees are planted at a density of 5,000 to $10,000 \mathrm{ha}^{-1}$, and the first harvest is made 18 and 24 months after planting (Kalil Filho et al., 2010; Steinmacher et al., 2011). The average yield is 0.8-1.2 stems per plant (Penteado et al., 2010).

Peach palm cultivation can be carried out under diverse climatic conditions. Optimal development is observed in hot

\footnotetext{
${ }^{1}$ Universidade Federal Rural do Rio de Janeiro (UFRRJ), Seropédica, RJ, Brasil

${ }^{2}$ Universidade de Taubaté (UNITAU), Taubaté, SP, Brasil
} 
and humid climate with average annual temperature of $21^{\circ} \mathrm{C}$, relative humidity of $80-90 \%$, and 2,000 $\mathrm{mm}$ of well-distributed rainfall (Neves et al., 2007). Trees require plenty of water to grow, but do not tolerate waterlogging. Supplemental irrigation may be necessary in water-deficient areas. Management of soil's physicochemical properties is needed to achieve high productivity. Palms prefer deep, well-drained, loamy to clayey soils rich in organic matter (Leandro et al., 2014; Neves et al., 2008). Soils deficient in $\mathrm{P}, \mathrm{N}, \mathrm{K}$, or $\mathrm{Mg}$ result in decreased growth (Viégas et al., 2009).

Proper crop residue management can improve the physicochemical characteristics of the soil, provide protection against erosion, and increase soil fertility (Souza \& PiñaRodrigues, 2013). Litterfall is the main pathway for nutrient transfer to the soil. Thus, knowledge of litter production and decomposition provides a basis for comprehending how an ecosystem functions (Herrera, 1989). The leaf fraction of litterfall has the highest nutrient density and is responsible for a faster transfer of macronutrients than the other fractions (Bianchin et al., 2016; Godinho et al., 2013; Machado et al., 2015; Marafiga et al., 2012; Pinto et al., 2016; Ribeiro et al., 2017). Litterfall decomposition and nutrient accumulation rates depend on several factors: climatic conditions, type of substrate, macronutrient content, and C/N/P ratios (Arco-Verde et al., 2009). In hot and humid climates or irrigated plantations, litterfall and crop residues usually decompose in 3 to 4 months (Malavolta et al., 1997).

This study aimed to determine litterfall and nutrient dynamics and seasonality in an experimental plantation of peach palm.

\section{MATERIALS AND METHODS}

Litterfall was collected between March 2010 and May 2011 on the experimental farm of the Department of Agricultural Sciences of the Universidade de Taubaté, Taubaté, SP, Brazil $\left(23^{\circ} 01^{\prime} 51^{\prime \prime} \mathrm{S} 45^{\circ} 30^{\prime} 34^{\prime \prime} \mathrm{W}, 565 \mathrm{~m}\right.$ altitude). The region is included in the Atlantic Forest domain in an area originally covered with seasonal semideciduous forest (IBGE, 2012). The average annual rainfall is $1,350 \mathrm{~mm}$; the average annual temperature, $21.9^{\circ} \mathrm{C}$ (Folhes \& Fisch, 2006).

Peach palm seedlings were planted in 1998 at a $2 \times 1 \mathrm{~m}$ spacing in red-yellow latosol previously cultivated with Urochloa decumbens (Stapf) R.D. Webster. The land was plowed and harrowed. Seedlings were fertilized at planting with $100 \mathrm{~kg} \mathrm{~N} \mathrm{ha}^{-1}$ as calcium ammonium nitrate, $35 \mathrm{~kg} \mathrm{P}_{2} \mathrm{O}_{5} \mathrm{ha}^{-1}$ as simple superphosphate, and $30 \mathrm{~kg} \mathrm{~K}_{2} \mathrm{O} \mathrm{ha}^{-1}$ as potassium chloride. Mowing was regularly performed where necessary, and residues were left on the soil surface. Fertilization with Borax at $2 \mathrm{~kg} \mathrm{ha}^{-1}$ was performed every three years.

Rainfall and temperature data were collected at a meteorological station close to the experimental site. These data are presented in Figure 1.

The total rainfall during the 15-month study period was $1,092.5 \mathrm{~mm}$. However, rainfall had an irregular distribution. In the study area, the dry season lasts from April to August. In 2010, $51.4 \mathrm{~mm}$ of rainfall were recorded in April and $0 \mathrm{~mm}$ in August. The rainy season began in September 2010, when rainfall increased considerably, and extended through March 2011. The highest rainfall amounts were recorded in January (214.0 mm) and March 2011 (206.8 mm) (Figure 1).

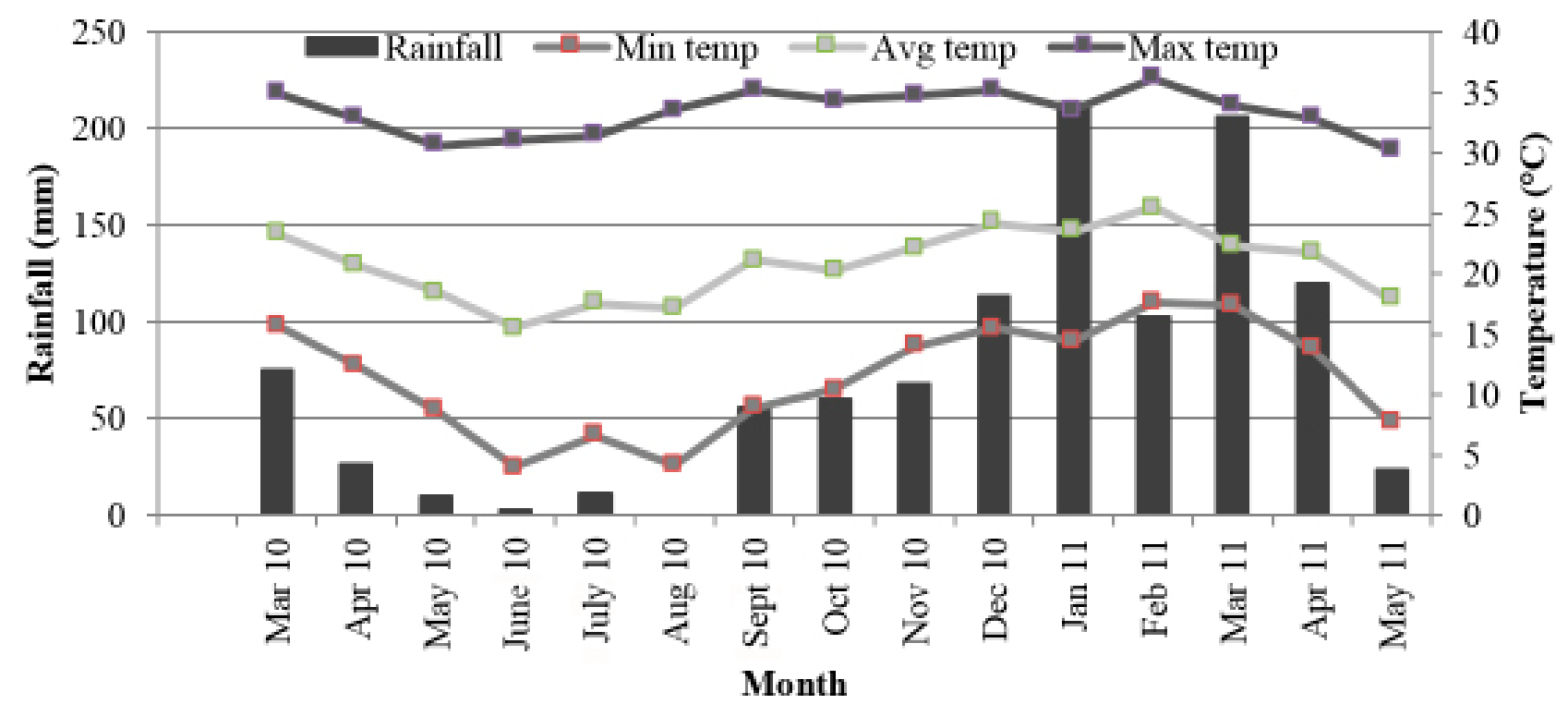

Figure 1. Monthly rainfall $(\mathrm{mm})$ and minimum, average, and maximum temperatures $\left({ }^{\circ} \mathrm{C}\right)$ from March 2010 to May 2011 in Taubaté, SP, Brazil. 
The minimum monthly temperature was lower from May to October 2010 (end of the dry season and beginning of the rainy season). The lowest $\left(4.0^{\circ} \mathrm{C}\right)$ and highest $\left(17.6^{\circ} \mathrm{C}\right)$ minimum temperatures were recorded in June 2010 and February 2011, respectively. The maximum monthly temperature was the lowest in May $2011\left(30.2^{\circ} \mathrm{C}\right)$ and the highest in February $2010\left(36.2^{\circ} \mathrm{C}\right)$. The mean average temperature during the experimental period was $20.6{ }^{\circ} \mathrm{C}$. The lowest $\left(15.6^{\circ} \mathrm{C}\right)$ and the highest (to $25.5^{\circ} \mathrm{C}$ ) average temperatures were recorded in June 2010 and February 2011, respectively (Figure 1).

Litterfall was collected monthly using 10 litter traps $\left(1 \mathrm{~m}^{2}\right)$ made of nylon mesh $(1 \mathrm{~mm})$. Litter traps were installed at $0.5 \mathrm{~m}$ from the ground surface at randomly selected sites within an area of 0.5 ha. Litterfall was separated into leaflet and rachis fractions and packed them separately in paper bags. In the laboratory, samples were dried in a forced air oven $\left(65^{\circ} \mathrm{C}, 72 \mathrm{~h}\right)$ for dry weight determination.

Litter fractions were milled using a Wiley-type mill and subjected to sulfuric acid digestion (Tedesco et al., 1995). N, $\mathrm{P}, \mathrm{K}, \mathrm{Ca}$, and $\mathrm{Mg}$ levels were determined. Two triplicates were performed, one corresponding to samples collected from litter traps one to five and the other, from litter traps six to ten. $\mathrm{N}$ content was determined through the micro Kjeldahl method. Metavanadate was used for the colorimetric determination of $\mathrm{P}$ content and absorbances were read on a conventional spectrophotometer. $\mathrm{K}, \mathrm{Ca}$, and $\mathrm{Mg}$ levels were determined by atomic absorption spectroscopy.

Results were subjected to the Shapiro-Wilk normality test and analysis of variance (ANOVA). Means were compared by Tukey's test at $\mathrm{p}<0.05$ and Pearson correlation coefficients were determined for litterfall and climate variables (rainfall, average, minimum, and maximum temperatures) using SISVAR version 5.3 (Ferreira, 2010).

\section{RESULTS AND DISCUSSION}

\subsection{Litter production}

Litterfall during the 15-month study period amounted to $9.2 \mathrm{Mg} \mathrm{ha}^{-1}$, of which $53 \%$ were leaflets and $47 \%$ were rachis. Litter deposition was the highest in October 2010, representing $24 \%$ of the total biomass accumulated in the study period (Figure 2).

Total litter biomass was lower than that observed by Herrera (1989) in peach palm plantations. The author reported a green weight production of $61.5 \mathrm{Mg} \mathrm{ha}^{-1}$ year $^{-1}$, which is equivalent to $19.5 \mathrm{Mg} \mathrm{ha}^{-1}$ year $^{-1}$ on a dry weight basis; of this total, only $1.76 \mathrm{Mg} \mathrm{ha}^{-1}$ year $^{-1}$ was harvested as heart of palm. Litter biomass accumulation might have been lower in this study because our sample included only leaves and rachis that naturally fell into the collector, whereas Herrera (1989) considered all plant residues generated from heart of palm extraction. Godinho et al. (2013) analyzed litterfall in a seasonal semideciduous forest and found a biomass accumulation of $9.3 \mathrm{Mg} \mathrm{ha}^{-1}$ year $^{-1}$.

The monthly percentage of litter fractions did not follow a well-defined pattern during the study period. Leaflet litter deposition ranged from 0.05 to $1.04 \mathrm{Mg} \mathrm{ha}^{-1} \mathrm{month}^{-1}$, and rachis litter deposition ranged from 0.00 to $1.19 \mathrm{Mg} \mathrm{ha}^{-1}$ month $^{-1}$ (Figure 3).

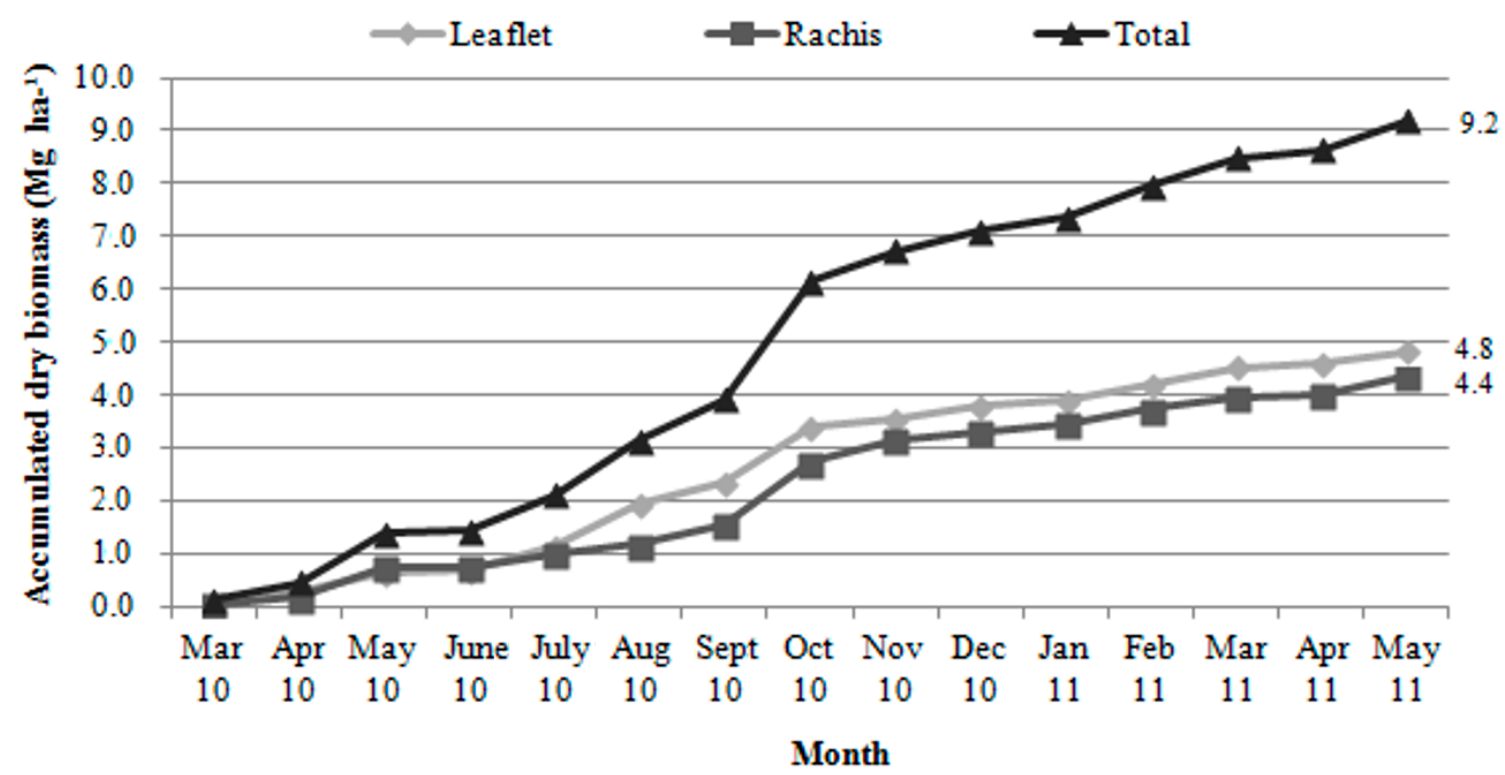

Figure 2. Biomass of litter and fractions (leaflet and rachis) produced in an experimental plantation of peach palm (Bactris gasipaes Kunth) from March 2010 to May 2011. 


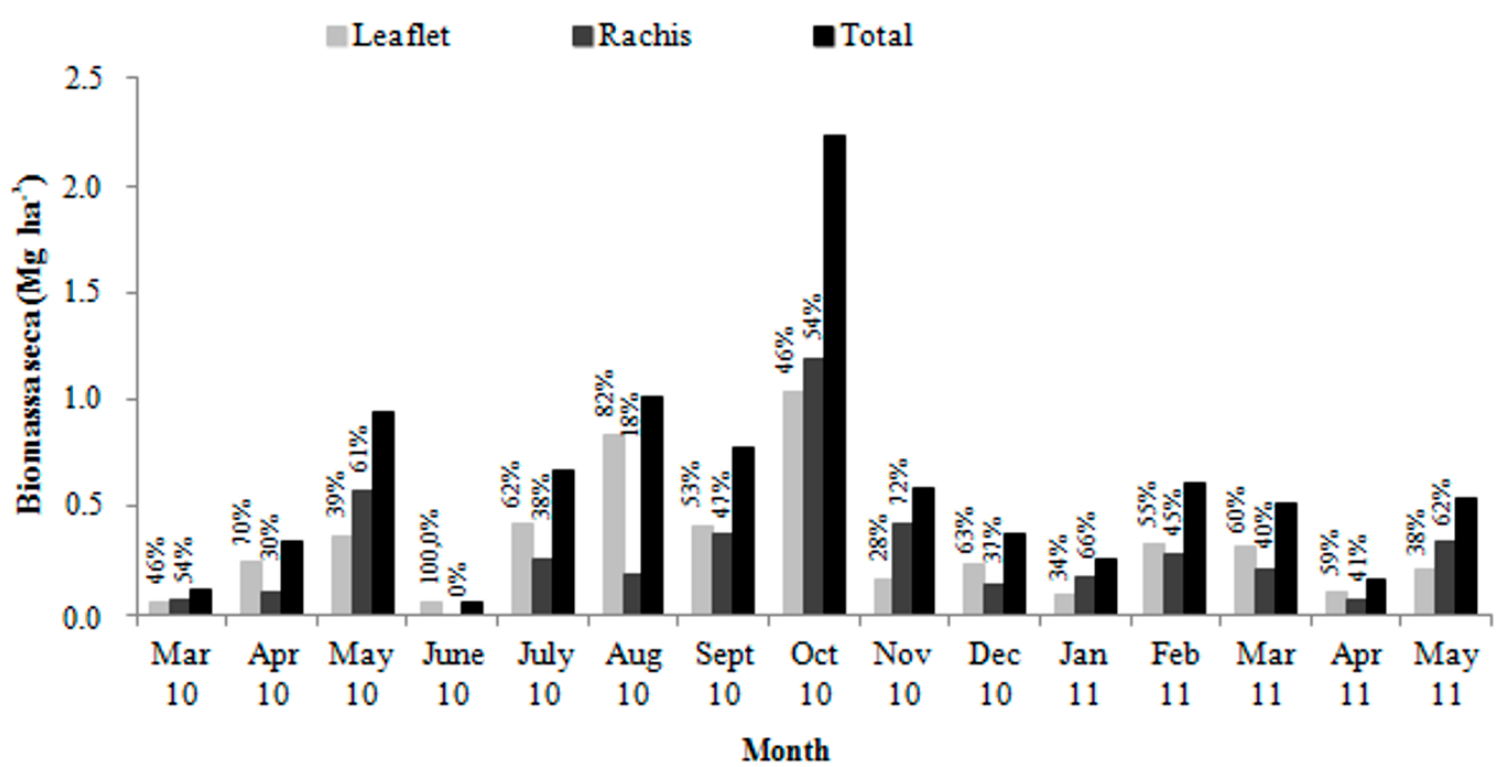

Figure 3. Monthly dry biomass of litter and fractions (leaflet and rachis) produced in an experimental plantation of peach palm (Bactris gasipaes Kunth) from March 2010 to May 2011. Percent values represent the proportion of leaflets and rachises in each litter sample.

The lowest litter depositions occurred in March 2010 (0.11 Mg ha $\left.{ }^{-1}\right)$, June $2010\left(0.05 \mathrm{Mg} \mathrm{ha}^{-1}\right)$, and April 2011 $\left(0.16 \mathrm{Mg} \mathrm{ha}^{-1}\right)$ (Figure 3). We observed the highest litter depositions, 0.94, 1.02, 0.78, and 2.23 $\mathrm{Mg} \mathrm{ha}^{-1}$, in May, August, September, and October 2010, respectively. This period corresponds to the end of the dry season and beginning of the rainy season, in which there was low rainfall and lower minimum temperatures. According to Clement, Kalil Filho et al. (2009), peach palms are in bloom during these months. Gomes et al. (2010) observed similar results in fragments of tropical rain forest - dense ombrophilous forest, according to the classification of the Brazilian Institute of Geography and Statistics (IBGE).

The seasonality of litterfall was corroborated by the negative significant correlation between litterfall and rainfall and litterfall and minimum temperature (Table 1). However, we observed no significant correlations between litterfall and average and maximum temperatures.

Table 1. Pearson correlation coefficients of litterfall with rainfall, minimum, average, and maximum temperatures in an experimental plantation of peach palm (Bactris gasipaes Kunth) from March 2010 to May 2011.

\begin{tabular}{cccc}
$\begin{array}{c}\text { Rainfall } \\
(\mathrm{mm})\end{array}$ & $\begin{array}{c}\text { Minimum } \\
\text { temperature } \\
\left({ }^{\circ} \mathrm{C}\right)\end{array}$ & $\begin{array}{c}\text { Average } \\
\text { temperature } \\
\left({ }^{\circ} \mathrm{C}\right)\end{array}$ & $\begin{array}{c}\text { Maximum } \\
\text { temperature } \\
\left({ }^{\circ} \mathrm{C}\right)\end{array}$ \\
$-0.34^{*}$ & $-0.34^{*}$ & $-0.14^{\mathrm{ns}}$ & $-0.02^{\mathrm{ns}}$ \\
\hline
\end{tabular}

* Significant at $\mathrm{p}<0.05 ;$ ns: not significant.
In contrast to our results, Gomes et al. (2010) observed a significant positive correlation between litterfall and rainfall, average, minimum, and maximum temperatures in a dense ombrophilous forest. Giácomo et al. (2012) investigated litterfall in seasonal semideciduous and cerradão forests and observed no correlation between litterfall and rainfall or litterfall and temperature.

The average temperature during the study period $\left(20.6^{\circ} \mathrm{C}\right)$ was suitable for peach palm development. However, rainfall had an irregular distribution. The ideal conditions for peach palm growth are average temperature of $21^{\circ} \mathrm{C}$ and uniform rainfall throughout the year (Neves et al., 2007). The total rainfall during the study period was lower than the average annual of $1,350 \mathrm{~mm}$ (Folhes \& Fisch, 2006) and far from the average annual considered appropriate for peach palm (2,000 mm) (Neves et al., 2007).

The seasonal distribution of litterfall can be explained by the findings of Carmo et al. (2003). The authors reported that peach palm has a rapid growth and vegetative development in the rainy period and, thus, a lower production of litter. Pinto et al. (2016) and Godinho et al. (2013) observed a similar litterfall pattern in seasonal semideciduous forests. The authors stated that, in tropical forests, litterfall occurs throughout the year but can vary according to the season. Higher litter production is observed in the dry season as a result of leaf abscission in response to water stress. However, Bianchin et al. (2016), Souza et al. (2016), and Villa et al. (2016) pointed out that high litter production can occur during high rainfall periods, especially in dense ombrophilous forests. 


\subsection{Litter nutrient content}

Nutrient contents varied according to litter fraction and season. In leaflets, nutrient content followed the order $\mathrm{N}>\mathrm{Ca}>\mathrm{K}>\mathrm{Mg}>\mathrm{P}$, whereas, in rachises, the order of nutrient concentration was $\mathrm{K}>\mathrm{N}>\mathrm{Ca}>\mathrm{Mg}>\mathrm{P}$ (Table 2).

Marafiga et al. (2012) observed the same order of nutrient concentration in leaflet litter collected in a seasonal semideciduous forest. In the study by Gomes et al. (2010), the nutrient content of litterfall collected in a dense ombrophilous forest followed the order $\mathrm{Ca}>\mathrm{K}>\mathrm{Mg}>\mathrm{P}$. Diniz et al. (2015) studied the nutrient composition of litter produced in Atlantic
Forest fragments at intermediate stages of succession and found the following order: $\mathrm{Ca}>\mathrm{N}>\mathrm{K}>\mathrm{Mg}>\mathrm{P}$.

In leaflets, $\mathrm{N}$ and $\mathrm{Ca}$ contents did not vary significantly between months, indicating that climatic conditions (dry/rainy seasons) did not affect these parameters (Table 2). P content was significantly higher in July 2010 than in February, April, and May 2011. K was significantly higher in May 2010 than in the other months but did not differ between May, June, July and August 2010 (Table 2). Mg content also varied over the months: it was significantly higher in August 2010 than in March, November, and December 2010 and January and April 2011 but did not vary between August 2010 and the other months.

Table 2. Nutrient content in peach palm (Bactris gasipaes Kunth) leaflet and rachis litter collected from March 2010 to May 2011.

\begin{tabular}{|c|c|c|c|c|c|c|}
\hline \multirow{2}{*}{ Sampling date } & \multicolumn{2}{|c|}{$\mathbf{N}\left(\mathrm{g} \mathrm{kg}^{-1}\right)$} & \multicolumn{2}{|c|}{$P\left(\mathrm{~g} \mathrm{~kg}^{-1}\right)$} & \multicolumn{2}{|c|}{$\mathrm{K}\left(\mathrm{g} \mathrm{kg}^{-1}\right)$} \\
\hline & Leaflet & Rachis & Leaflet & Rachis & Leaflet & Rachis \\
\hline March 2010 & $13.31 \mathrm{Aa}$ & $8.40 \mathrm{Ab}$ & $1.64 \mathrm{ABCa}$ & $1.27 \mathrm{BCDb}$ & $2.59 \mathrm{CDb}$ & $5.05 \mathrm{BCDEa}$ \\
\hline April 2010 & $16.11 \mathrm{Aa}$ & $7.00 \mathrm{ABb}$ & $1.74 \mathrm{ABCa}$ & $1.55 \mathrm{BCDb}$ & $3.92 \mathrm{BCDb}$ & $13.58 \mathrm{Aa}$ \\
\hline May 2010 & $12.96 \mathrm{Aa}$ & $4.20 \mathrm{ABb}$ & $1.81 \mathrm{ABb}$ & $2.16 \mathrm{ABa}$ & $9.69 \mathrm{Aa}$ & $7.80 \mathrm{BCb}$ \\
\hline June 2010 & $12.04 \mathrm{Aa}$ & $0.00 \mathrm{Bb}$ & $1.45 \mathrm{ABCDa}$ & $0.00 \mathrm{~Eb}$ & $5.41 \mathrm{ABCDa}$ & $0.00 \mathrm{~Eb}$ \\
\hline July 2010 & $15.06 \mathrm{Aa}$ & $4.55 \mathrm{ABb}$ & $1.91 \mathrm{Ab}$ & $2.71 \mathrm{Aa}$ & $7.04 \mathrm{ABCb}$ & $9.98 \mathrm{ABa}$ \\
\hline August 2010 & $13.66 \mathrm{Aa}$ & $4.90 \mathrm{ABb}$ & $1.82 \mathrm{ABb}$ & $2.74 \mathrm{Aa}$ & $8.27 \mathrm{ABa}$ & $7.33 \mathrm{BCb}$ \\
\hline September 2010 & $11.73 \mathrm{Aa}$ & $4.55 \mathrm{ABb}$ & $1.36 \mathrm{ABCDb}$ & $2.04 \mathrm{ABCa}$ & $3.53 \mathrm{BCDb}$ & $6.75 \mathrm{BCDa}$ \\
\hline October 2010 & $14.01 \mathrm{Aa}$ & $4.37 \mathrm{ABb}$ & $1.77 \mathrm{ABCb}$ & $2.07 \mathrm{ABCa}$ & $4.06 \mathrm{BCDb}$ & $6.15 \mathrm{BCDa}$ \\
\hline November 2010 & $11.91 \mathrm{Aa}$ & $7.35 \mathrm{ABb}$ & $1.71 \mathrm{ABCa}$ & $1.45 \mathrm{BCDb}$ & $3.91 \mathrm{BCDb}$ & $6.14 \mathrm{BCDa}$ \\
\hline December 2010 & $12.43 \mathrm{Aa}$ & $4.02 \mathrm{ABb}$ & $1.20 \mathrm{ABCDa}$ & $1.49 \mathrm{BCDb}$ & $2.07 \mathrm{CDb}$ & $5.05 \mathrm{BCDEa}$ \\
\hline January 2011 & $14.88 \mathrm{Aa}$ & $4.72 \mathrm{ABb}$ & $1.30 \mathrm{ABCDa}$ & $1.36 \mathrm{BCDa}$ & $2.59 \mathrm{CDb}$ & $6.95 \mathrm{BCDa}$ \\
\hline February 2011 & $13.15 \mathrm{Aa}$ & $7.81 \mathrm{ABb}$ & $0.87 \mathrm{BCDa}$ & $0.60 \mathrm{DEb}$ & $1.12 \mathrm{Da}$ & $0.28 \mathrm{~Eb}$ \\
\hline March 2011 & $12.95 \mathrm{Aa}$ & $3.70 \mathrm{ABb}$ & $0.98 \mathrm{ABCDb}$ & $1.31 \mathrm{BCDa}$ & $1.70 \mathrm{CDb}$ & 3.64 CDEa \\
\hline April 2011 & $11.55 \mathrm{Aa}$ & $4.60 \mathrm{ABb}$ & $0.61 \mathrm{Db}$ & $1.14 \mathrm{CDa}$ & $0.70 \mathrm{Db}$ & $5.96 \mathrm{BCDa}$ \\
\hline May 2011 & $11.25 \mathrm{Aa}$ & $5.95 \mathrm{ABb}$ & $0.77 \mathrm{CDb}$ & $0.98 \mathrm{DEa}$ & $1.22 \mathrm{Db}$ & $1.64 \mathrm{DEa}$ \\
\hline Mean & $13.13 \mathrm{a}$ & $5.08 \mathrm{~b}$ & $1.40 \mathrm{~b}$ & $1.52 \mathrm{a}$ & $3.86 \mathrm{~b}$ & $5.75 \mathrm{a}$ \\
\hline Standard deviation & 1.41 & 2.06 & 0.43 & 0.74 & 2.70 & 3.53 \\
\hline \multirow{2}{*}{ Sampling date } & \multicolumn{2}{|c|}{$\mathrm{Ca}\left(\mathrm{g} \mathrm{kg}^{-1}\right)$} & \multicolumn{2}{|c|}{$\operatorname{Mg}\left(\mathrm{g} \mathrm{kg}^{-1}\right)$} & & \\
\hline & Leaflet & Rachis & Leaflet & Rachis & & \\
\hline March 2010 & $4.45 \mathrm{Aa}$ & $2.66 \mathrm{ABb}$ & $2.28 \mathrm{CDb}$ & $2.35 \mathrm{Aa}$ & & \\
\hline April 2010 & $5.31 \mathrm{Aa}$ & $1.67 \mathrm{ABb}$ & $3.67 \mathrm{ABa}$ & $1.66 \mathrm{Ab}$ & & \\
\hline May 2010 & $5.31 \mathrm{Aa}$ & $1.67 \mathrm{ABb}$ & $3.32 \mathrm{ABCa}$ & $1.48 \mathrm{Ab}$ & & \\
\hline June 2010 & $4.97 \mathrm{Aa}$ & $0.00 \mathrm{Bb}$ & $3.14 \mathrm{ABCDa}$ & $0.00 \mathrm{Bb}$ & & \\
\hline July 2010 & $5.44 \mathrm{Aa}$ & $2.00 \mathrm{ABb}$ & $3.66 \mathrm{ABa}$ & $1.74 \mathrm{Ab}$ & & \\
\hline August 2010 & $4.98 \mathrm{Aa}$ & $1.00 \mathrm{ABb}$ & $3.89 \mathrm{Aa}$ & $1.65 \mathrm{Ab}$ & & \\
\hline September 2010 & $4.29 \mathrm{Aa}$ & $1.80 \mathrm{ABb}$ & $2.82 \mathrm{ABCDa}$ & $1.88 \mathrm{Ab}$ & & \\
\hline October 2010 & $5.08 \mathrm{Aa}$ & $2.03 \mathrm{ABb}$ & $3.51 \mathrm{ABCa}$ & $1.78 \mathrm{Ab}$ & & \\
\hline November 2010 & $4.31 \mathrm{Aa}$ & $2.72 \mathrm{ABb}$ & $2.37 \mathrm{BCDa}$ & $1.98 \mathrm{Ab}$ & & \\
\hline December 2010 & $4.21 \mathrm{Aa}$ & $2.60 \mathrm{ABb}$ & $1.96 \mathrm{Db}$ & $2.22 \mathrm{Aa}$ & & \\
\hline January 2011 & $4.11 \mathrm{Aa}$ & $1.83 \mathrm{ABb}$ & $1.97 \mathrm{Da}$ & $1.41 \mathrm{Ab}$ & & \\
\hline February 2011 & $5.86 \mathrm{Aa}$ & $3.34 \mathrm{Ab}$ & $2.58 \mathrm{ABCDa}$ & $2.01 \mathrm{Ab}$ & & \\
\hline March 2011 & $5.40 \mathrm{Aa}$ & $1.82 \mathrm{ABb}$ & 2.99 ABCDa & $1.43 \mathrm{Ab}$ & & \\
\hline April 2011 & $4.66 \mathrm{Aa}$ & $2.47 \mathrm{ABb}$ & $1.92 \mathrm{Db}$ & $2.11 \mathrm{Aa}$ & & \\
\hline May 2011 & $4.46 \mathrm{Aa}$ & $2.53 \mathrm{ABb}$ & $2.87 \mathrm{ABCDa}$ & $2.22 \mathrm{Ab}$ & & \\
\hline Mean & $4.86 \mathrm{a}$ & $2.01 \mathrm{~b}$ & $2.86 \mathrm{a}$ & $1.73 \mathrm{~b}$ & & \\
\hline Standard deviation & 0.54 & 0.80 & 0.67 & 0.56 & & \\
\hline
\end{tabular}

Means followed by different uppercase letters in a column and lowercase letters in a row within each nutrient differ at $\mathrm{p}<0.05$ by Tukey's test. N: nitrogen; P: phosphorus; K: potassium; Ca: calcium; Mg: magnesium. 
In rachises, $\mathrm{N}$ content was only significantly higher in March 2010 compared with June 2010 (Table 2). The levels of $\mathrm{P}$, which did not differ significantly, were significantly higher in March, April, June, November, and December 2010, and January and May 2011. K concentration was significantly higher in April 2010 in comparison with the other months, except in July 2010 (Table 2). The level of Ca was only higher in February 2011 than in June 2010. Mg was significantly lower in July 2010 but did not vary in the other months.

Mean N, Ca, and Mg contents were significantly higher in leaflets than in rachises: leaflets contained respectively $72 \%, 71 \%$, and $62 \%$ of the total $\mathrm{N}, \mathrm{Ca}$, and $\mathrm{Mg}$ in litterfall. On the other hand, mean $\mathrm{P}$ and $\mathrm{K}$ levels were significantly higher in rachises, which contained respectively $52 \%$ and $60 \%$ of the total $\mathrm{P}$ and $\mathrm{K}$ in litterfall.

Throughout the study period, $\mathrm{N}$ concentration in leaflets was lower than the recommended $\left(25-40 \mathrm{~g} \mathrm{~N} \mathrm{~kg}^{-1}\right)$ for peach palm leaflets (Fernandes et al., 2013; Silva \& Falcão, 2002). Similarly, K concentration was lower than the optimal (8-27.8 $\left.\mathrm{g} \mathrm{K} \mathrm{kg}^{-1}\right)$ in all months except May and August 2010, when $\mathrm{K}$ concentrations were within the ideal range (Fernandes et al., 2013; Silva \& Falcão, 2002).

From March to November 2010, except September, $\mathrm{P}$ concentration in leaflets was within the recommended levels, that is, between 1.5 and $3.6 \mathrm{~g} \mathrm{~kg}^{-1}$ (Fernandes et al., 2013; Silva \& Falcão, 2002). However, between December 2010 and May 2011, P content was lower than the optimal. During this period, rainfall was higher, litter production was lower, and P might have been redirected from the leaflet to the fruit during fruit ripening (Clement, Kalil Filho et al., 2009).

$\mathrm{Ca}$ and $\mathrm{Mg}$ contents were within the appropriate levels for leaflets, 2.0-12.7 $\mathrm{g} \mathrm{Ca} \mathrm{kg}^{-1}$ and 2.0-3.5 $\mathrm{g} \mathrm{Mg} \mathrm{kg}^{-1}$ (Fernandes et al., 2013; Silva \& Falcão, 2002).

\subsection{Nutrient cycling via litterfall}

The amount of nutrient return through litterfall varied during the study period. The mean nutrient input followed the order $\mathrm{N}>\mathrm{K}>\mathrm{Ca}>\mathrm{Mg}>\mathrm{P}$ (Table 3).

Villa et al. (2016) observed that the concentration of nutrients recycled through litterfall in a 12-year-old dense ombrophilous forest followed the order $\mathrm{N}>\mathrm{Ca}>\mathrm{K}>\mathrm{Mg}>\mathrm{P}$, similar to that found in our study. Diniz et al. (2015) observed a different order of nutrient content in litterfall of semideciduous forest fragments at intermediate succession stages $(\mathrm{Ca}>\mathrm{N}>\mathrm{K}>\mathrm{Mg}>\mathrm{P})$ and advanced succession stages $(\mathrm{N}>\mathrm{Ca}>\mathrm{K}>\mathrm{Mg}>\mathrm{P})$.

Table 3. Nutrient return via litterfall in an experimental plantation of peach palm (Bactris gasipaes Kunth) from March 2010 to May 2011.

\begin{tabular}{|c|c|c|c|c|c|c|c|c|c|c|}
\hline Sampling date & \multicolumn{2}{|c|}{$\mathbf{N}\left(\mathrm{kg} \mathrm{ha}^{-1}\right)$} & \multicolumn{2}{|c|}{$P\left(\mathrm{~kg} \mathrm{ha}^{-1}\right)$} & \multicolumn{2}{|c|}{$\mathrm{K}\left(\mathrm{kg} \mathrm{ha}^{-1}\right)$} & \multicolumn{2}{|c|}{$\mathrm{Ca}\left(\mathrm{kg} \mathrm{ha}^{-1}\right)$} & \multicolumn{2}{|c|}{$\operatorname{Mg}\left(\mathrm{kg} \mathrm{ha}^{-1}\right)$} \\
\hline March 2010 & 1.21 & B & 0.16 & B & 0.44 & B & 0.40 & B & 0.26 & B \\
\hline April 2010 & 4.58 & B & 0.58 & B & 2.34 & $\mathrm{AB}$ & 1.44 & B & 1.05 & B \\
\hline May 2010 & 7.13 & $\mathrm{AB}$ & 1.90 & $\mathrm{AB}$ & 8.02 & $\mathrm{AB}$ & 2.89 & $\mathrm{AB}$ & 2.06 & $\mathrm{AB}$ \\
\hline June 2010 & 0.73 & B & 0.09 & B & 0.33 & B & 0.30 & B & 0.19 & B \\
\hline July 2010 & 7.40 & $\mathrm{AB}$ & 1.47 & $\mathrm{AB}$ & 5.43 & $\mathrm{AB}$ & 2.76 & $\mathrm{AB}$ & 1.96 & $\mathrm{AB}$ \\
\hline August 2010 & 12.27 & $\mathrm{AB}$ & 2.02 & $\mathrm{AB}$ & 8.24 & $\mathrm{AB}$ & 4.33 & $\mathrm{AB}$ & 3.54 & $\mathrm{AB}$ \\
\hline September 2010 & 12.86 & $\mathrm{AB}$ & 2.65 & $\mathrm{AB}$ & 8.56 & $\mathrm{AB}$ & 4.73 & $\mathrm{AB}$ & 3.63 & $\mathrm{AB}$ \\
\hline October 2010 & 39.35 & A & 8.71 & A & 25.93 & A & 14.87 & A & 11.46 & A \\
\hline November 2010 & 10.11 & $\mathrm{AB}$ & 1.98 & $\mathrm{AB}$ & 7.85 & $\mathrm{AB}$ & 3.67 & $\mathrm{AB}$ & 2.42 & $\mathrm{AB}$ \\
\hline December 2010 & 6.95 & $\mathrm{AB}$ & 1.06 & B & 2.74 & $\mathrm{AB}$ & 2.67 & $\mathrm{AB}$ & 1.50 & B \\
\hline January 2011 & 4.13 & B & 0.92 & B & 2.87 & $\mathrm{AB}$ & 1.57 & B & 1.01 & $\mathrm{~B}$ \\
\hline February 2011 & 13.10 & $\mathrm{AB}$ & 1.00 & B & 1.15 & B & 5.95 & $\mathrm{AB}$ & 2.93 & $\mathrm{AB}$ \\
\hline March 2011 & 9.33 & $\mathrm{AB}$ & 1.14 & $\mathrm{AB}$ & 2.11 & $\mathrm{AB}$ & 4.08 & $\mathrm{AB}$ & 2.48 & $\mathrm{AB}$ \\
\hline April 2011 & 2.99 & B & 0.27 & B & 0.41 & B & 1.24 & B & 0.75 & B \\
\hline May 2011 & 9.33 & $\mathrm{AB}$ & 0.81 & B & 1.75 & $\mathrm{AB}$ & 4.17 & $\mathrm{AB}$ & 2.52 & $\mathrm{AB}$ \\
\hline Mean & 9.43 & & 1.65 & & 5.21 & & 3.67 & & 2.52 & \\
\hline Standard deviation & 9.18 & & 2.09 & & 6.50 & & 3.51 & & 2.70 & \\
\hline Total & 141.46 & & 24.76 & & 78.17 & & 55.07 & & 37.77 & \\
\hline
\end{tabular}

Means followed by the same uppercase letters in a column do not differ at $\mathrm{p}<0.05$ by Tukey's test. N: nitrogen; P: phosphorus; K: potassium; Ca: calcium; Mg: magnesium. 
The content of macronutrients ( $\mathrm{N}, \mathrm{P}, \mathrm{K}, \mathrm{Ca}$, and $\mathrm{Mg}$ ) was significantly higher in litter produced in October 2010 than in March, April, and June 2010 and January and April 2011 (Table 3). The amount of $\mathrm{N}$ recycled was the highest among nutrients during the study period, reaching $41.9 \%$ of the sum of nutrients returned. P was the least recycled nutrient, totaling only $7.3 \%$ of the sum of nutrients. Of this percentage, about $30 \%$ was returned to the soil in October 2010. There were months in which $P$ return was less than $100 \mathrm{~g} \mathrm{ha}^{-1}$. The amount of $\mathrm{K}$ returned to the soil via litterfall was $78.2 \mathrm{~kg} \mathrm{ha}^{-1}$, which represents $23.2 \%$ of the sum of nutrients returned. This amount is sufficient to meet the short-term nutrient requirements of peach palm. According to Ares et al. (2003), $60-70 \mathrm{~kg} \mathrm{ha}^{-1}$ of $\mathrm{K}$ is necessary to meet the minimum requirements for peach palm growth. The amount of $\mathrm{Ca}$ and $\mathrm{Mg}$ returned accounted respectively for $16.3 \%$ and $11.2 \%$ of the sum of nutrients returned.

Although the amounts of nutrients returned in October 2010 were not significantly higher than that in other months (Table 2), the higher values are explained by the higher amount of leaflets and rachises produced in this month (Figure 3). Various authors report that the nutrient content in litter can vary according to soil and climate conditions and plant age (Gomes et al., 2010; Diniz et al., 2015; Villa et al., 2016).

The results show that peach palms produce a large amount of litter, which favors the cycling of N, P, K, Ca, and Mg. Herrera (1989), Silva \& Falcão (2002), and Fernandes et al. (2013) obtained similar findings.

\section{CONCLUSIONS}

We observed a seasonal pattern of peach palm litter production, as climate conditions influenced the monthly litterfall. The highest litterfall occurred at the end of the dry season and beginning of the rainy season, months in which there was low rainfall and low minimum temperatures. The concentration of macronutrients in leaflets followed the order $\mathrm{N}>\mathrm{Ca}>\mathrm{K}>\mathrm{Mg}>\mathrm{P}$, whereas, in rachis, nutrient content followed the order $\mathrm{K}>\mathrm{N}>\mathrm{Ca}>\mathrm{Mg}>\mathrm{P}$. During the 15-month study period, the accumulated litterfall was 9.2 $\mathrm{Mg} \mathrm{ha}^{-1}$ (4.8 $\mathrm{Mg} \mathrm{ha}^{-1}$ of leaflets and $4.4 \mathrm{Mg} \mathrm{ha}^{-1}$ of rachises). In total, $141.5 \mathrm{~kg} \mathrm{ha}^{-1}$ of $\mathrm{N}, 24.8 \mathrm{~kg} \mathrm{ha}^{-1}$ of P, $78.2 \mathrm{~kg} \mathrm{ha}^{-1}$ of $\mathrm{K}, 55.1 \mathrm{~kg} \mathrm{ha}^{-1}$ of $\mathrm{Ca}$, and $37.8 \mathrm{~kg} \mathrm{ha}^{-1}$ of $\mathrm{Mg}$ were returned to the soil through litterfall.

\section{ACKNOWLEDGEMENTS}

Conselho Nacional de Desenvolvimento Científico e Tecnológico (CNPq) and Coordenação de Aperfeiçoamento de Pessoal de Nível Superior (CAPES).

\section{SUBMISSION STATUS}

Received: 28 Apr. 2018

Accepted: 30 Mar. 2019

Associate editor: Eduardo Vinicius da Silva

\section{CORRESPONDENCE TO}

\section{Marcos Gervasio Pereira}

Universidade Federal Rural do Rio de Janeiro (UFRRJ), BR 465, km 7, CEP 23890-000, Seropédica, RJ, Brasil

e-mail: mgervasiopereira01@gmail.com

\section{REFERENCES}

Anefalos LC, Tucci MLS, Modolo VA. Uma visão sobre a pupunheira no contexto de mercado de palmito. Análises e Indicadores do Agronegócio 2007; 2(7): 1-6.

Arco-Verde MF, Silva IC, Mourão M Jr. Aporte de nutrientes e produtividade de espécies arbóreas e de cultivos agrícolas em sistemas agroflorestais na Amazônia. Floresta 2009; 39(1): 11-22. 10.5380/rf.v39i1.13721

Ares A, Falcão N, Yuyama K, Yost RS, Clement CR. Response to fertilization and nutrient deficiency diagnostics in peach palm in Central Amazonia. Nutrient Cycling in Agroecosystems 2003; 66: 221-223. 10.1023/A:1024458823052

Bianchin JE, Marques R, Britez RM, Capretz RL. Deposição de fitomassa em formações secundárias na Floresta Atlântica do Paraná. Floresta e Ambiente 2016; 23(4): 524-533. 10.1590/2179-8087.134015

Bovi ML. Expansão do cultivo da pupunheira para palmito no Brasil. Horticultura Brasileira 1997; 15(Suppl): 183-185.

Carmo CAFS, Eira PA, Santos RD, Bernard ACC, Gomes JF, Naime $\mathrm{UJ}$ et al. Aspectos culturais e zoneamento da pupunha no estado do Rio de Janeiro. Rio de Janeiro: Embrapa Solos, 2003.

Carvalho AV, Vasconcelos MAM, Silva PA, Ascheri JLR. Produção de snacks de terceira geração por extrusão de misturas de farinhas de pupunha e mandioca. Brazilian Journal of Food Technology 2009; 12(4): 277-284. 10.4260/BJFT2009800900022

Chaimsohn FP. Cultivo de pupunha e produção do palmito. Viçosa, MG: Aprenda Fácil; 2010.

Clement CR, Kalil Filho AN, Modolo VA, Yuyama K, Rodrigues DP, Van Leeuwen J et al. Domesticação e melhoramento de pupunha. In: Borém A, Lopes MTG, Clement CE, editors. Domesticação e melhoramento: espécies amazônicas. Viçosa, MG: Editora UFV, 2009. p. 367-398.

Clement CR, Rival L, Cole DM. Domestication of peach palm (Bactris gasipaes Kunth): the roles of human mobility and migration. In: Alexiades MN, editor. Shifting spaces, changing times: mobility, migration and displacement in indigenous lowland South America. Oxford, UK: Berghahn Books; 2009. p. 117-140.

Cymerys M, Clement CR. Pupunha (Bactris gasipaes Kunth). In: Shanley P, Medina G. Frutíferas e plantas úteis na Amazônia. Belém: CIFOR, IMAZON; 2005. 
Diniz AR, Machado DL, Pereira MG, Balieiro FC, Menezes CEG. Biomassa, estoques de carbono e de nutrientes em estádios sucessionais da Floresta Atlântica, RJ. Revista Brasileira de Ciências Agrárias 2015; 10(3): 443-451. 10.5039/agraria.v10i3a4264

Empresa Brasileira de Pesquisa Agropecuária - EMBRAPA. A cultura da pupunha. Brasília-DF: Embrapa-SPI; 1995. (Coleção Plantar, 25).

Fernandes AR, Matos GSB, Carvalho JG. Deficiências nutricionais de macronutrientes e sódio em mudas de pupunheira. Revista Brasileira de Fruticultura 2013; 35(4): 1178-1189. 10.1590/S010029452013000400029

Ferreira DF. SISVAR: sistema de análises de variância para dados balanceados. Lavras: UFLA; 2010.

Folhes MT, Fisch G. Caracterização climática e estudo de tendências nas séries temporais de temperatura do ar e precipitação em Taubaté (SP). Revista Ambiente e Água 2006; 1(1): 61-71. 10.4136/ambi-agua.6

Fonseca EBA, Moreira MA, Carvalho JG. Cultura da pupunheira (Bactris gasipaes Kunth). Lavras: UFLA; 2001. (Boletim de Extensão, 29).

Giácomo RG, Pereira MG, Machado DL. Aporte e decomposição de serapilheira em áreas de cerradão e mata mesófila na estação ecológica de Pirapitinga, MG. Ciência Florestal 2012, 22(4): 669680. $10.5902 / 198050987549$

Godinho TO, Caldeira MVW, Caliman JP, Prezotti LC, Watzlawick LF, Azevedo HCA, Rocha JHT. Biomassa, macronutrientes e carbono orgânico na serapilheira depositada em trecho de floresta estacional semidecidual submontana, ES. Scientia Florestalis 2013; 41(97): 131-144.

Golley FB, McGinnis JT, Clements RG, Child GI, Duever MJ. Ciclagem de minerais em um ecossistema de floresta tropical úmida. São Paulo: EPU-EDUSP; 1983.

Gomes JM, Pereira MG, Pinã-Rodrigues FCM, Pereira GHA, Godim FR, Silva EMR. Aporte de serapilheira e de nutrientes em fragmentos florestais de Mata Atlântica, RJ. Revista Brasileira de Ciências Agrárias 2010; 5(3): 383-391. 10.5039/agraria.v5i3a552

Herrera W. Fertilización del pejibaye para palmito. Boletín Informativo 1989; 1(2): 4-10.

Instituto Brasileiro de Geografia e Estatística - IBGE. Manual técnico da vegetação brasileira. 2nd ed. Rio de Janeiro: IBGE; 2012.

Jackson JF. Seasonality of flowering and leaf-fall in a Brazilian subtropical lower montane moist forest. Biotropica 1978; (10)1: 38-42. $10.2307 / 2388103$

Kalil Filho NA, Clement CR, Resende MDV, Farias Neto JT, Bergo CL, Yokomizo GKI et al. Programa de melhoramento genético de pupunha na Embrapa, IAC e INPA. Colombo: Embrapa Florestas; 2010.

Leandro RC, Yuyama K, Coelho ECS, Menezes JMT, Feitosa IL. Estimativa de altura, diâmetro e número de folhas em pupunheiras para palmito, submetidas a diferentes espaçamentos e níveis de adubação, na Amazônia. Revista Sodebras 2014; 9(101): 34-39.

Lorenzi H. Flora brasileira: Arecaceae (palmeiras). Nova Odessa: Instituto Plantarum; 2010.

Lorenzi H, Souza HM, Costa JTM, Cerqueira LSC, Ferreira E. Palmeiras brasileiras e exóticas cultivadas. Nova Odessa: Instituto Plantarum; 2004.

Machado DL, Pereira MG, Correia MEF, Diniz AR, Santos LL, Menezes CEG. Ciclagem de nutrientes em diferentes estágios sucessionais da Mata Atlântica na bacia do rio Paraíba do Sul,
RJ. Bioscience Journal 2015; 31(4): 1222-1237. 10.14393/BJv31n1a2015-23092

Malavolta E, Vitti GC, Oliveira SA. Avaliação do estado nutricional das plantas: princípios e aplicações. 2nd ed. Piracicaba: Potafos; 1997.

Marafiga JS, Vieira M, Szymczak DA, Schumacher MV, Trüby P. Deposição de nutrientes pela serapilheira em um fragmento de floresta estacional decidual no Rio Grande do Sul. Revista Ceres 2012; 59(6): 765-771. 10.1590/S0034-737X2012000600005

Meguro M, Vinueza GN, Delitti WBC. Ciclagem de nutrientes minerais na mata mesófila secundária: São Paulo: I: produção e conteúdo de nutrientes minerais no folhedo. Boletim de Botânica 1979; 7: 11-31. 10.11606/issn.2316-9052.v7i0p11-31

Molina E. Fertilización y nutrición de pejibaye para palmito. San José: Centro de Investigaciones Agronómicas; 1997. (Research report).

Neves EJM, Santos AF, Matins EG, Rodigheri HR, Bellettini S, Corrêa C Jr. Cultivo da pupunheira para produção de palmito. In: Santos AF, Corrêa C Jr, Neves EJM, editors. Palmeiras para a produção de palmito: juçara, pupunheira e palmeira real. Colombo: Embrapa Florestas; 2008. p. 39-64.

Neves EJM, Santos AF, Rodrigheri HR, Corrêa C Jr, Bellettini S, Tessamann DJ. Cultivo da pupunheira para palmito nas regióes Sudeste e Sul do Brasil. Colombo: Embrapa Florestas; 2007. (Circular Técnica, 143).

Palm CA, Sanchez PA. Nitrogen release from the leaves of some tropical legumes as affected by their lignin and polyphenolic contents. Soil Biology and Biochemistry 1991; 23(1): 83-88. 10.1016/00380717(91)90166-H

Penteado JF Jr, Santos AF, Neves EJM. Rentabilidade econômica do cultivo da pupunheira (Bactris gasipaes Kunth), destinada à produção de palmito no Litoral de Santa Catarina. Colombo: Embrapa Florestas; 2010. (Documentos, 195).

Pinto HCA, Barreto PAB, Gama-Rodrigues EF, Oliveira FGRB, Paula A, Amaral AR. Decomposição da serapilheira foliar de floresta nativa e plantios de Pterogyne nitens e Eucalyptus urophylla no sudoeste da Bahia. Ciência Florestal 2016; 26(4): 1141-1153. $10.5902 / 1980509825105$

Raij BV, Cantarella H. Outras culturas industriais. In: Raij BV, Cantarella H, Quaggio JA, Furlani AMC, editors. Recomendações para adubação e calagem para o estado de São Paulo. $2 \mathrm{~d}$ ed. Campinas: Instituto Agronômico; 1996. p. 97-101. (Boletim Técnico, 100).

Ribeiro FP, Bussinguer AP, Hodecker BER, Gatto A. Conteúdo de nutrientes na serapilheira em três fisionomias do cerrado do Distrito Federal. Pesquisa Florestal Brasileira 2017; 37(92): 465-473. 10.4336/2017.pfb.37.92.1312

Silva JRA, Falcão NPS. Caracterização de sintomas de carências nutricionais em mudas de pupunheira cultivadas em solução nutritiva. Acta Amazonica 2002; 32(4): 529-539. 10.1590/180943922002324539

Sousa EP, Soares NS, Cordeiro AS, Silva ML. Competitividade da produção de palmito de pupunha no Espírito Santo e em São Paulo. Economia e Sociologia Rural 2011; 49(1): 157-180. 10.1590/ S0103-20032011000100007

Souza MCS, Piña-Rodrigues FCM. Desenvolvimento de espécies arbóreas em sistemas agroflorestais para recuperação de áreas degradadas na floresta ombrófila densa, Paraty, RJ. Revista Árvore 2013; 1(37): 89-98. 10.1590/S0100-67622013000100010 
Souza MCS, Piña-Rodrigues FCM, Casagrande JC, Silva SF, Scoriza RN. Funcionalidade ecológica de sistemas agroflorestais biodiversos: uso da serapilheira como indicador da recuperação de áreas de preservação permanente. Floresta 2016; 46(1): 75-82. 10.5380/ rf.v46i1.34991

Steinmacher DA, Guerra MP, Saare-Surminski K, Lieberei R. A temporary immersion system improves in vitro regeneration of peach palm through secondary somatic embryogenesis. Annals of Botany 2011; 108(8): 1463-1475. 10.1093/aob/mcr033

Tedesco MJ, Gianello C, Bissani CA, Bohnen H, Volkweiss SJ. Análises de solo, plantas e outros materiais. 2nd ed. Porto Alegre: UFRGS; 1995. (Boletim Técnico, 5).
Viégas IJM, Meireles RO, Frazão DAC, Conceição HEO. Avaliação da fertilidade de um latossolo amarelo textura média para o cultivo do açaizeiro no estado do Pará. Revista de Ciências Agrárias 2009; (52): 23-36.

Villa EB, Pereira MG, Alonso JM, Beutler SJ, Leles PSS. Aporte de serapilheira e nutrientes em área de restauração florestal com diferentes espaçamentos de plantio. Floreta e Ambiente 2016; 23(1): 90-99. 10.1590/2179-8087.067513

Yuyama K, Chávez WB, Pereira BG, Silva IA. Efeito da densidade de plantas e adubação NPK na produção inicial de palmito de pupunheira. Revista Brasileira de Ciência do Solo 2005; 29(3): 373378. 10.1590/S0100-06832005000300007 